\title{
A CASE STUDY ON WILLINGNESS TO COMMUNICATE IN ENGLISH IN THE IRANIAN TERTIARY EDUCATIONAL CONTEXT
}

\author{
Zahra Alimorad $^{\mathrm{a}}$, Mina Farahmand ${ }^{\mathrm{b}}$ \\ (a zahra.alimorad@shirazu.ac.ir, ${ }^{\mathrm{b}}$ mina.fmd72@gmail.com) \\ Department of Foreign Languages and Linguistics \\ Shiraz University, Eram Square, Shiraz, Iran
}

\begin{abstract}
Willingness to communicate (WTC) in English is specifically important because L2 (foreign/second language) communication is considered to be a key factor in L2 learning. When the opportunity to speak English arises, there are generally two options: speaking or avoiding it. Several factors might exert influence on the choice of either option by different individuals. In this vein, the current study investigated the underlying factors that lead to (un)willingness on the part of Iranian EFL (English as a Foreign Language) tertiary students. Through a purposive sampling procedure, this classroom-based case study recruited and examined 10 EFL learners in Iran over a period of three weeks. Data were collected employing semi-structured interviews, classroom observations and stimulated-recall interviews. Thematic analysis was performed to identify common themes from the participating students' ideas. Results reveal that participants' L2 WTC emerges as a result of the complex, dynamic and non-linear interaction between individual, contextual, and linguistic factors. These three factors interdependently exerted either facilitative or inhibitive impacts on an individual student's WTC in class at any point in time. The current study, therefore, reinforces the need for teachers to be aware of the multiple factors which lead learners to be more or less willing to communicate in L2 classrooms.
\end{abstract}

Keywords: facilitating and impeding factors, more-and-less-willing-tocommunicate learners, willingness to communicate (WTC)

DOI: http://dx.doi.org/10.15639/teflinjournal.v32i1/1-28

Willingness to communicate (WTC) has been a hotly debated topic among scholars of language learning. It was originally introduced by McCroskey and 
Baer (1985) as they discussed communication in L1. Later, MacIntyre and Charos (1996) adapted WTC to the L2 situation. McCroskey and Richmond (1990) define WTC as an individual's tendency to start communication when free to do so. That is, those language learners who are willing to communicate in the L2 actively seek out opportunities to communicate, and in fact, they do communicate. McCroskey and Richmond (1990) assume WTC to function as a personality trait, showing stable individual differences across different communication situations and types of receivers. This implies situational variables might influence one's willingness to communicate, but every individual manifests regular WTC tendencies across communication contexts.

Arguing that the ultimate goal of L2 education is to train students who are willing to use the language, MacIntyre et al. (1998) maintain that the goal of the learning process should be set to pique learners' interest to willingly seek communication opportunities and make use of those opportunities. Having this in mind, psychology of communication and affective factors need to be examined as the variables affecting WTC (Yashima, 2002). MacKinnon et al. (2007) also pointed out that the choice to speak or be silent is an important factor in the EFL learners' success. Both individual factors (anxiety, motivation, attitudes, interpersonal attraction, etc.) and social contextual factors (ethno-linguistic vitality, language contact, etc.) can affect WTC (MacIntyre, 2007).

Previous studies, such as Khajavy et al. (2018), MacIntyre et al. (2003), Robson (2015), Yashima et al. (2004), to name a few, examined WTC mainly through quantitative methods using questionnaires which may not be informative enough to analyze situational characteristics of WTC within actual contexts. This study differs from previous studies in that it examined foreign language learners' WTC within the microsystem of the Iranian EFL classroom context, using a qualitative research design. To do that, the analytical framework of the current study was based on the emergent model of L2 WTC in the Iranian EFL context by Khajavy et al. (2014). Given that in their study, L2 WTC was explored using a quantitative analysis, they call for additional studies using qualitative analyses to provide a more holistic picture of WTC by investigating potential situational and individual variables that are involved and how these individual variables can interact with situational variables in creating WTC. In response to their call, this research delves into the issue of WTC by interviewing and observing a purposive sample of Iranian EFL university 
students and investigates the factors which lead to high levels of WTC among Iranian EFL learners who are more-willing-to-communicate (hereafter moreWTC) and those which lead to low levels of WTC among less-willing-tocommunicate (hereafter less-WTC) learners. Furthermore, it attempts to compare and contrast the factors mentioned by the two groups to come to some conclusions regarding the most important factors affecting Iranian EFL learners' WTC. To address the above-mentioned objectives, this research asks the following questions.

1. Which factors contribute to higher and lower levels of WTC in moreWTC and less-WTC Iranian EFL university students in English language classes?

2. How do the factors mentioned by the first and second groups of language learners compare?

\section{LITERATURE REVIEW}

Different researchers have attempted to examine L2 WTC from various perspectives throughout the world. For instance, arguing that a quantitative method using questionnaires is insufficient to investigate the situational characteristics of WTC in an actual context, Kang (2005) examines L2 WTC through a qualitative method using videotaped conversations, interviews, and stimulated recalls. Findings of his study suggested that situational WTC was dynamic and could vary according to the influence of contextual variables such as interlocutor(s), topic and conversational context during communication. These variables interacted with the psychological conditions of security, excitement and responsibility to determine the degree of L2 WTC.

In another study, Cao and Philp (2006) investigate the trait-like versus the situational nature of WTC. By implementing classroom observations in three different interactional situations (pair work, group work and whole class), they found a mismatch between learners' self-report of WTC and their actual classroom behavior. Based on learners' perceptions, four main factors of group size, self-confidence, familiarity with interlocutors and interlocutor participation in the conversation were the emerged factors. Other researchers were also mindful of the learners' perceptions of factors influencing their WTC. In the Turkish EFL context, Öz et al. (2015), for instance, found motivation through the intervention of communication apprehension and self- 
perceived communication competence indirectly affected L2 WTC. As for the Iranian context, Riasati (2012) investigated Iranian learners' perceptions of such factors pointing out the role played by task type, topic of discussion, age and sex of the interlocutor, class atmosphere, personality, self-perceived speaking ability and teachers in learners' WTC. The role of teachers was also studied by Zarrinabadi (2014) who found that teachers' wait time, error correction, decision on the topic, and support not only enhance the amount of student participation in communication but also affect their tendency to communicate in future situations.

In 2011, MacIntyre and Legatto investigated the fluctuations in WTC over a very short period of time and came to the conclusion that WTC changed remarkably over the few minutes during which the participants carried out the tasks. Respondents mostly attributed their decline in WTC to the inability to find L2 vocabulary items required to perform the task. In a similar vein, the impact of language anxiety and language proficiency on WTC in the Iranian EFL context was studied by Alemi et al. (2011). Results indicated that Iranian university students' WTC directly correlated with their language proficiency. While inside the classroom context, lower proficient learners exhibited lower WTC compared to those with higher language proficiency, surprisingly, they were more communicative than higher proficient ones outside the classroom. However, no significant interaction was found between WTC and anxiety.

In order to examine the relations among classroom environment, anxiety, enjoyment, and WTC, Khajavy et al. (2018) used doubly latent multilevel analysis to address the need to examine positive and negative emotional influences on WTC together with modeling classroom-level effects. Based on the results, the correlation between enjoyment and WTC was stronger than that between anxiety and WTC suggesting that WTC was greater in those individuals who experienced enjoyment during learning. Moreover, although girls' WTC and anxiety was rather higher, no difference was observed between boys and girls in terms of enjoyment. Also, while classroom environment exerted a positive influence on both enjoyment and WTC, it affected anxiety negatively.

More recently, Mystkowska-Wiertelak (2018) explored WTC fluctuations of a single student named Peter who outperformed all other group members over the course of one semester. Results suggested that contextual variables had a significant impact on his WTC and self-perceived communicative 
competence was a dominant predictor of his WTC in the instructional setting. Additionally, his WTC was highest in game-like activities, thereby suggesting the significance of the nature of the task itself. This case study of a single student implied that motivating warm-up activities could increase WTC by creating a better state of mind for the rest of the lesson. Likewise, allowing students to have a chance to revise words or to prepare for a speaking activity had the potential to increase WTC. The study has, to some extent, contributed to a better understanding of fluctuations in language learners' L2 WTC in instructional settings; nevertheless, it needs to be borne in mind that monitoring one single exceptional student affects the study outcomes and questions its generalizability.

In a more recent study, attempting to examine the effect of personality and past experience on university students' L2 WTC, Freiermuth and Ito (2020) interviewed eight female Japanese students using a semi-structured interview framework. Their findings revealed that participants with high L2 WTC viewed themselves as future L2 users rather than mere consumers and were stimulated through integrative motivation with their fellow students and teachers. Results of their study also pointed out positive personality traits can facilitate WTC by indicating that positive past experiences with language teachers and foreign peers can lead to a better understanding of second language learners' WTC.

From the review of L2 WTC studies carried out in different contexts, it can be seen that previous studies on L2 WTC predominantly employed questionnaires to measure its trait-like nature. Cao and Philp (2006) questioned these questionnaires to be generic and not specifically designed for an instructional setting and called for the development of a separate L2 WTC classroom instrument. Furthermore, recent theoretical studies have suggested observation method to be more appropriate to tap situational WTC, which may change across contexts, and have also pointed to the need to consider L2 WTC across situational contexts (Cao \& Philp, 2006; Kang, 2005).

Moreover, as the review of the literature suggests, Iranian EFL learners' perception of factors contributing to WTC has gone rather unnoticed. This brief glimpse through the literature on WTC helped reveal that although the history of research on the concept enjoys a good amount of depth and breadth, few were done in Iran (e.g., Fallah, 2014; Ghonsooly et al., 2012; Riasati, 2012; Zarrinabadi, 2014). Moreover, most of these studies were conducted through quantitative methods (e.g., Alemi et al., 2011; Khajavy et al., 2018). To the 
best of the present researchers' knowledge, very few qualitative studies were done in Iran (e.g., Riasati, 2012; Zarrinabadi, 2014). Riasati (2012), for instance, sought Iranian EFL learners' perception of factors that affected their willingness to speak English in language classrooms. The focus of his study, however, was on language learners in a private language institute. Additionally, although Zarrinabadi's (2014) qualitative study was conducted in the university context, he used focused essays as the only data collection tool. To fill these gaps, the present study intended to uncover the factors underlying WTC based on learners' perceptions through a case study on both more- and less-WTC university students by utilizing various data collection tools (i.e., interviews, observations, and stimulated recalls).

\section{METHOD}

\section{Participants}

Ten Iranian undergraduate freshman university students (male $=2$, female $=8$ ) of English Language and Literature were recruited to participate in this study. At the outset, 12 students (six with low-WTC and six with highWTC) gave their consent to participate in this study, but after the first phase of data collection, two of them refused to continue due to personal reasons (one male and one female). The sampling procedure was purposive in that those students who were identified to be more/less willing to communicate in EFL classes, as determined by their two teachers based on their amount of participation in English speaking classes, were chosen. All participants were Iranian students who spoke Persian as their native language. Their age ranged from 18 to 26 years old. Freshman students were chosen because they mainly study different language skills in the first two semesters; therefore, compared to other university levels, they may have more opportunities to speak in the classes. Due to ethical considerations, pseudonyms are used throughout the paper.

\section{Researchers' Roles}

In this study, the two researchers shared responsibility in the following way. While the second researcher was primarily deemed responsible to collect the data, this phase was carried out under the full control and careful guidance of the first researcher who was the supervisor of this study. That is, prior to the 
data collection phase, they held several meetings together during which the supervisor explained the procedures, checked the instruments, resolved potential ambiguities, and tried to predict and alleviate possible problems.

\section{Instruments}

\section{General Interviews Prior to Observations}

Learners' perceptions of the factors contributing to their WTC in classes were elicited through semi-structured interviews. Before observing the classes, the participants were asked questions relating to the antecedents of WTC; that is, which factors led to their (un)willingness to participate in classroom discussions and (not) express their ideas. Interviews were conducted in students' mother tongue because it was assumed that English may have acted as a barrier to the concise and clear expression of their ideas (Alimorad, 2013). Overall, 34 questions were asked in these interviews which were adapted from Cao and Philp (2006), Peng (2012) and Yashima et al. (2016). First, the participants provided some demographic information and then, they were asked questions regarding their experiences in learning and using English, and factors that may have influenced their WTC.

\section{Classroom Observations}

In the context of this study, freshman students should do three English skills courses: Speaking and Listening, Grammar and Writing, and Reading Comprehension. To have a clearer picture of their WTC, eight sessions were observed by the second researcher. The number of sessions each class was observed was determined based on this researcher's success in interviewing the participants after the classes (i.e., stimulated recall interviews). Various factors affected her success in this phase including the students' having enough time after each class, or not being tired or sick. Overall, each student was observed for eight sessions. Furthermore, the students were only observed in a whole class setting. To observe the classes, a WTC classroom observation scheme (Cao, 2011) was employed which was divided into eight categories, each of which was coded in a table (See the appendix).

Observations were conducted under natural classroom conditions, and the participants were observed during normal classroom activities. The two instructors were aware of the specific objectives of the research and the fact 
that it was the students, rather than the teacher, who were the focus of the study; therefore, they did not feel under any pressure to perform differently. It is worth mentioning that of the three courses, two of them were taught by the same teacher (Grammar and Writing; and Listening and Speaking); that is why there were two instructors for the three classes. The observer in this study attempted to be unobtrusive so as not to have any impact on what was being observed (Johnson \& Christensen, 2008); as such, she sat near the front of the classroom to one side where she could observe each of the participants in the room but could avoid physically obtruding between the instructor and the students.

\section{Stimulated Recall Interviews after Observations}

To encourage accurate recall, stimulated recall interviews were immediately deployed after observing each class. As mentioned above, eight sessions of their classes were observed; however, each student was interviewed only once after each class and hence, each participant had three stimulated recall interviews after their three different classes. In this phase, the participants commented on their performance while they individually listened to excerpts of the audio recordings of their performance in the classroom. That is, they expressed their reasons for (not) participating in classroom discussions. Because some participants were more willing to talk than others, the amount of time for each participant differed. These interviews were also conducted in Persian by the second researcher. Twenty-eight questions asked in these interviews were adapted from Cao and Philp (2006), Cao (2011, 2014), and Yashima et al. (2016). These questions mainly addressed the nature of the participants' situational WTC in classes.

\section{Data Collection and Analysis Procedures}

The data were collected in three main phases in three weeks. The first stage focused on conducting semi-structured interviews. In the second phase, the participants' conversations in different classes were observed and recorded on audiotapes. Finally, for each participant, three stimulated recall interviews were conducted on the previously audio-taped conversations of their three different classes. During the first and the third phases of data collection (i.e., interviews), in order to build up mutual understanding and trust with the interviewees (Johnson \& Christensen, 2008), they were notified of the 
objectives of the study and reassured that their responses would be anonymous and confidential. Interviews took between 10 and 20 minutes, depending on the amount of detail each participant was ready to provide.

To analyze the collected data, first, the audio recordings of the students' speech were transcribed verbatim in Persian and then translated into English by the researchers for the purpose of analysis. Then, thematic analysis was used to analyze the interview data. To ensure the reliability of the analyses, memberchecking (Ary et al., 2019) was employed by asking each participant to compare their original ideas with the translations and interpretations done by the researchers. If they confirmed them, it could safely be assumed that the findings of the study could be trusted. Discrepancies were resolved through discussion.

The techniques employed to decrease subjectivity and increase the likelihood of producing credible findings for this study were back-translation, member checks, low-inference descriptors, triangulation of data, and intra- and inter-coder agreement. Low-inference descriptors such as verbatim or direct quotations were used to help the reader see the setting and experience the participants' world (Ary et al., 2019). The current study utilized methods (interview and observation) triangulation, i.e., using more than one method, on the assumption that the combination of methods leads to a better verification (Ary et al., 2019). In order to evaluate the dependability of this study, intra- and inter-coder agreement strategies were used, the indexes of which were $95 \%$ and $92 \%$, respectively.

\section{Ethical Considerations}

Ethical issues including informed consent, privacy, anonymity and confidentiality were given very serious consideration during the entire process of this study. To be more precise, at the outset of the study, the participants were made completely aware of the objectives of this research so that they would not feel any compulsion before taking part. During the interview process, they were informed that their interviews were to be recorded. They were also assured that their privacy would be maintained and the information they shared would only be used for the current study. Informants had the right to withdraw and not to participate further at any stage of the data collection (the case with two of the participants). Furthermore, the participants were reassured that their (non-)participation would not affect their grade or relationship with 
the instructors in any way. They were also ensured that the given information would not disclose their identity.

\section{FINDINGS AND DISCUSSIONS}

\section{Facilitating and Impeding Factors of WTC in Iranian EFL Classrooms}

Based on the analytical framework of the study, factors reported by the participants as contributing to their situational WTC were classified into three categories: individual, contextual, and linguistic. However, because of space limitations, in each section, just a few illustrative examples of the participants' responses are given. Also, it is worthy of notice that because the interviews were in Persian, all the direct quotations reported in this section are translations.

\section{Individual Factors}

The students reported they would be willing to talk when a suitable opportunity arose. Laura, for instance, commented, "I think the best opportunities to speak English in class are when the teachers themselves allow us to talk; then, we can speak comfortably" (General interview). Some students felt that their WTC was hindered by over-talkative students who took up most of the opportunities to talk, especially in a whole-class situation. As Reihaneh noted, "I wanted to talk but other students talked too much; so, I couldn't [talk]" (Stimulated recall interview). In line with this finding, previous studies also found perceived opportunity for talking as a variable leading to WTC (Cao, 2011; Cao \& Philp, 2006; House, 2004).

In addition to perceived opportunity to communicate, students' personalities were also a determining factor. For instance, Tahmoores, an ebullient and talkative student among his classmates, described himself as an extroverted and a sociable student, "As I'm a sociable person, it's easy for me to speak in different situations. Generally, I feel more confident when I'm with other people" (General interview). In contrast, Elahe commented, "Generally, I'm silent, I like to listen more." (Stimulated recall interview). Previous research also indicated that personality can either facilitate or hinder language learning in general and learners' WTC specifically (MacIntyre \& Charos, 1996; MacIntyre et al., 1998), so that extrovert, impulsive, social and flexible students tend to be more risk-taking and inclined to communicate (Wen \& 
Clément, 2003). In a similar vein, Freiermuth and Ito (2020) came to the conclusion that in the context of Japan, weaknesses in L2 competency can be compensated for by individual personalities such as extraversion and openness to experiences and all these variables contribute to a high level of L2 WTC.

Anxiety, on the other hand, negatively affected the students' WTC. As an example, Shin reported, "I'm nervous when I'm speaking in front of others. I don't show it but I'm under a lot of stress" (General interview). Participants' interviews suggested that the major element underlying their anxiety was fear of being humiliated because of making mistakes. For example, in one of her stimulated recall interviews, Donya stated: "I was anxious and a bit afraid of saying something unpleasant or making mistakes and being laughed at by my classmates."

In the present study, anxiety seemed to have mainly affected less-WTC participants. In fact, none of more-WTC students reported that they were anxious while speaking. The less-WTC participants frequently maintained that they were worried about the language use which included the use of grammar, structure, and vocabulary. Shin, a less-WTC student, voiced that she was concerned about her vocabulary use: "I was a little nervous while I was speaking. I thought about my vocabularies, whether they were right or not. I also thought about being criticized by others." (Stimulated recall interview).

Whole-class situation where peer pressure was felt could also trigger anxiety. As Shin mentioned, "In a presentation, you are speaking in front of a class, all students are looking at you, it's like you really have something important to say and they have to listen to you. That makes me nervous." (Stimulated recall interview).

Two participants, Amir Ali and Farnoosh, who appeared less anxious about losing face, expressed high WTC in the classroom, "I have come here to learn and even if I make any mistake, I would be happy to be corrected" (General interview). Farnoosh agreed, "I know sometimes I made a mistake, but everyone can make a mistake" (General interview). Regarding anxiety, the findings of this study support previous studies that suggest a high level of anxiety is associated with low class participation and low motivation (e.g., Clément et al., 1994). de Saint Léger and Storch (2009) also confirmed that an environment engendering high anxiety is improbable to be favorable to WTC or, indeed, to learning. 
Contrary to anxiety which was mainly observed in less-WTC students, almost all high-WTC participants along with some less-WTC ones reported self-confidence. Shin was an example of a less-WTC participant who said, "I'm quite confident while speaking in class and I don't have any problem" (General interview). Elahe, who had low WTC during observations, was an example of a less confident participant: "I'm trying to be more confident. Although others praise me, I don't have the confidence that I should have" (General interview). Previous studies (Baker \& MacIntyre, 2003; Cao, 2009; Cetinkaya, 2005; Clément et al., 2003; Fallah, 2014; Ghonsooly et al., 2012; Kim, 2004; MacIntyre et al., 2001; Peng \& Woodrow, 2010; Yashima, 2002; Yashima et al., 2004) have also identified self-confidence as an individual variable that has an immediate effect on WTC.

The participants' level of confidence fluctuated as a result of their interlocutors' proficiency level as stated by Bamdad,

It depends on the interlocutors. If you are speaking with those who are more knowledgeable than you, it affects the way you are speaking. But if they are the same as you or lower than you, you can speak more easily and you are more confident. (General interview)

In our study, students expressed a range of emotions as factors influencing their WTC in class including negative emotions such as anxiety, frustration, embarrassment and anger, and positive emotions such as enjoyment and satisfaction. Reihaneh, the student who demonstrated relatively high WTC, expressed annoyance and irritation at her classmates' reaction to her mistake,

At first, I really felt like talking but when those two people laughed at me, I was really angry at first. But then I said to myself that they aren't worth it, so I just quietly listened to the rest of the discussions. (Stimulated recall interview)

Another student, Amir Ali, also pointed out a quite similar experience,

There are some people in our class that are ready to react to your mistakes. As soon as you make a minor mistake, five or six people simultaneously say, 'What? No, it's not correct.' Well, this isn't good at all. It really makes me annoyed and every now and then, I can't control myself and react to their behavior. (Stimulated recall interview)

Research on emotion suggests that academic emotions influence the quality of students' learning as well as that of classroom communication. Students experience a diverse range of emotions in instructional settings. Aside 
from negative emotions such as anxiety that have been repeatedly reported, positive emotions are mentioned as frequently (Goetz et al., 2006; Pekrun, 2000; Pekrun et al., 2002). However, compared to positive emotions, negative ones were more frequently reported by the students in this study; specifically, negative emotions about their classmates' behaviors. For instance, Farnoosh maintained, "Sometimes he [Tahmoores] really gets on my nerves. Honestly, I don't have any serious problem with him but I feel he is too young. He judges others too quickly and questions different groups conclusively. Overall, he is judgmental." (Stimulated recall interview). After the same class, Tahmoores also expressed his annoyance at Farnoosh's reactions,

I was thinking about how critical she likes to be. She didn't pay enough attention to what I was saying and the point that I was talking about something different. I wish she noticed more so that there was not so much conflict. (Stimulated recall interview)

A few students, on the other hand, expressed enjoyment and satisfaction with class activities and their willingness to engage in a conversation with their classmates. As an example, Elahe maintained, "Well, I like the book; I mean I understand what we are studying. And the way the teacher treats us and the fact that we are studying together, all of these together make me like it." (Stimulated recall interview)

Contrary to this finding, Khajavy et al.'s (2014) framework considered anxiety as the only negative emotional reaction; however, as discussed above, results of this research and previous studies reveal that positive emotions as well as a diverse range of negative ones could have an impact on learners' WTC. Therefore, it could be argued that such findings could shed more light and enrich previous theoretical frameworks on WTC.

\section{Contextual Factors}

Learners of English in this study reported that they were more willing to communicate when the interlocutor was familiar because friends or familiar interlocutor(s) made them feel more confident to speak without being selfconscious about their mistakes. This is obvious in the following excerpts: "It is easy for me to speak when I know someone for a while, and I have no shame." (Shin, General interview) "I feel more willing to talk when I both have the knowledge about the topic and feel relaxed to talk with those people in the conversation." (Elahe, General interview) This finding supports the results of 
other studies (Cao \& Philp, 2006; Liu, 2005) which found that the more familiar the students were with their interlocutors, the more comfortable they felt talking to them.

As one of the other contextual factors, teachers were perceived to act as an incentive to encourage the students to talk. As Elahe remarked, "His teaching style is really good. I'm completely concentrated in the class. And the classroom atmosphere is not tense. It's fun so I can learn well" (Stimulated recall interview). Laura had a similar opinion: "My happiness was our teacher. $\mathrm{He}$ is really good, and I really like the way he teaches" (Stimulated recall interview). Additionally, the students were inclined to be more willing to ask questions and engage actively in class activities when they liked the teacher of that class. As Farnoosh commented, "It's easier for me to ask questions in Dr. X's [teacher's name] class" (Stimulated recall interview). Conversely, the teacher could also have a negative effect on students' WTC in class. Farnoosh later noted, "I didn't like to talk more because I think Dr. X [teacher's name] was upset about me. Apparently, he was not in a good mood for me. So, I decided to remain silent." (Stimulated recall interview)

This finding lends support to the results of previous studies which claimed that in the classroom context, teachers exert a profound effect on students' WTC. Wen and Clément (2003), for instance, indicated that teachers' involvement, attitude, immediacy and teaching style exert a significant and pivotal sociocultural influence on student participation and WTC. Pattapong (2010), too, reported the influence of teacher characteristics and teaching practice on learners' WTC in her study on Thai students' WTC.

Besides interlocutors, topic of the discussion, too, served as a factor contributing to students' WTC. Lack of content knowledge or unfamiliarity with the topic appeared to be another debilitating factor in decreasing WTC. In this study, most of the participants explicitly mentioned that if they were unfamiliar with or unprepared for the topic, they would more likely be unwilling to communicate. "Generally, I like to express my ideas when the topic of discussion is familiar to me." (Donya, General interview) "If I don't have any familiarity with the topic or I'm not prepared for it, it's hard for me to talk." (Hoda, General Interview)

Regarding background knowledge of a topic, empirical research across different contexts has consistently revealed that learners feel much more secure and willing to speak if they have enough background knowledge of the topic 
(e.g., Cao \& Philp, 2006; Kang, 2005). However, culturally sensitive topics could create negative feelings. As Farnoosh said, "Our beliefs and dogmas are too open; because of that, maybe, I'm not comfortable to talk about some topics". She continued,

Usually, it's easy for me to talk, discussions which are not sensitive or controversial. I don't mean that if it is controversial, I sit quietly and say nothing. In fact, I CANNOT. But it's easier to talk when the topic of our discussion is not sensitive like religious issues. (General interview)

This was in contrast to Kang's (2005) findings which indicated students tended to be more willing when the topics dealt with sensitive issues in relation to their country or culture. This discrepancy might be due to the context of the study. The current research was conducted in an EFL context where all the participants were from the same culture and country. In Kang's (2005) study, however, the participants were from different cultures and countries that were learning English in an ESL country (USA). They felt a sense of responsibility to talk about topics dealing with sensitive issues in relation to their country or culture, which might have given negative impressions about their country.

Nature of the task and task difficulty as two aspects of task orientation were found to have affected the participants' WTC. Bamdad commented in a stimulated recall interview after the grammar class, "I had the feeling to talk in today's class but well, grammar class doesn't need much talk" Although the participants of this study liked grammar, they believed that grammar tasks did not provide them with much room to speak. However, in Pattapong's (2010) study, the participants were less willing to communicate because they disliked grammar tasks.

Regarding willingness to give presentations, while less-WTC students were reluctant to give presentations in the classroom, more-WTC ones did not have any problem presenting their ideas. Farnoosh, for example, said, "It's interesting to give presentations in the classroom context because you can get feedback from teachers and other students," (General interview). Reihaneh was too eager to give presentations, "I like to give a presentation for an hour and a half because I like others feel that my English language is as good as my native language," (General interview). On the other hand, Hoda stated that, "I'm not that much willing to give presentations," (General interview). Previous studies, too, identified task type as a factor affecting students' WTC in pair and group interactions (Cao \& Philp, 2006; Peng, 2008). 
In addition to the nature of the task, its level of difficulty can maximize or minimize the participants' WTC. In this study, almost all the participants regarded the tasks to be easy for their level of proficiency and found them not to be challenging and stimulating. For example, Amir Ali, a more-WTC student, commented, "It's a little boring for me because the reading text doesn't have many new vocabularies," (Stimulated recall interview). In a similar vein, Tahmoores pointed out that, "The proficiency level of our class is much higher than the book which is taught to us," (Stimulated recall interview). In contrast to the current study, learners in MacIntyre and Legatto's (2011) study were consistently more willing to do a task in an L2 when it was easy, but once it was perceived to be more difficult, participants' willingness slowed noticeably and eventually ended in deteriorated performance leading learners to revert to L1.

The only classroom interactional pattern observed in this study was wholeclass interaction which was perceived by some students as anxiety-provoking due to peer pressure; that is, they felt anxious and uncomfortable giving incorrect answers in front of their classmates. To clarify the point, as Elahe mentioned, "When the teacher asks me a question, I will be shocked to answer immediately. I have to fully concentrate in order to be able to give the correct answer," (General interview). More specifically, less-WTC participants mainly preferred to talk in pairs and small groups because there would be less competition in turn-taking,

I feel most comfortable in small group and pairs. The reason is that I feel relaxed and there are people whom I communicate with most and I know them and we are friends with each other. (Donya, General interview)

All in all, while less-WTC students preferred to talk in pairs and small groups, more-WTC ones claimed that it did not make that much difference for them to talk in different situations. This finding supports previous studies which showed that in a conversational context, the number of interlocutors involved in a communication, or more precisely, group size, seemed to have an impact on WTC (Kang, 2005; McCroskey \& Richmond, 1991). de Saint Leger and Storch (2009) also found that the participants perceived whole-class discussion as the most difficult type of interactional pattern due to peer pressure. 


\section{Linguistic Factors}

The linguistic factor refers to competence factors such as self-perceived L2 proficiency or achievement. In the present study, lack of lexical resources could affect the students' communication with others. For example, during her general interview, Elahe stated that "My general L2 proficiency is good. The only problem is that I have limited vocabulary knowledge and that makes me get stressed sometimes." Likewise, Hoda, who was reticent even in the interviews, commented, "When we were at high school, we had to study subjects which didn't have any relationship with English. So, we don't know a vast number of vocabularies." (General interview)

Similarly, de Saint Leger and Storch (2009) reported that vocabulary was an area of concern that impeded the students' oral interaction whereas grammar and pronunciation were less perceived as troublesome. Cao (2009) also found that having difficulty with the comprehension of keywords in an article or oral language resulted in reduced willingness to talk in the L2. Likewise, Liu (2005) identified the lack of vocabulary knowledge as a source of student unwillingness in oral English language classrooms.

Generally speaking, those students who had a higher level of L2 proficiency perceived themselves as more competent to communicate in English and felt less anxious to engage in classroom discussions. For instance, Farnoosh perceived her speaking level to be native-like,

My English is as good as my own native language. I feel comfortable communicating in English as much as in my own language. I cannot say my speaking is exactly at a native level but it's nearly native-like. And maybe communicating in English is more comfortable for me than in Persian. (General interview)

This finding is in line with Khajavy et al. (2014) in that in their study, those students who perceived themselves more competent felt less anxious and, in turn, had higher levels of WTC. As a strong factor in their emergent model, they suggested the degree of a person's L2 proficiency has a significant effect on his/her WTC. Other empirical studies also indicated that lower levels of linguistic proficiency could restrain students from risking to speak the L2 in class (Liu \& Jackson, 2008). However, the same finding seems to be in contrast to what Freiermuth and Ito (2020) found in the context of Japan. In their study, individual personalities such as extraversion and openness to experiences were 
found to compensate for L2 competency weaknesses and all of these constructs in tandem contributed to higher levels of L2 WTC. Their finding points out the possible mediating role personality factors can play in L2 WTC studies, which merits further investigation through quantitative studies.

Based on the above-mentioned findings, in response to the research questions, it could be argued that factors contributing to WTC reflected three main dimensions of individual, contextual and linguistic. The individual dimension concerned internal affective factors including perceived opportunity to communicate, personality, anxiety, self-confidence and emotions. The contextual dimension included external factors of interlocutor(s), topic, task orientation, teacher, and classroom interactional pattern. Finally, the linguistic dimension was mainly concerned with self-perceived language proficiency as a competence factor.

Regarding the comparison between the factors mentioned by more- and less-WTC participants, some appeared to be common factors among the two groups. Besides their personalities, both groups pointed to the need for an appropriate opportunity to talk. Generally, extravert and sociable students tended to be more willing to communicate while anxiety appeared to have mainly influenced less-WTC participants negatively. The present study also found self-confidence to be a major contributing factor to WTC. Remarks by both more- and less-WTC participants suggested that emotions, too, had an impact on the quantity of their classroom communication.

Interlocutor, topic and task orientation were among the contextual variables that both groups referred to as influential factors. They were more willing when the topic and the interlocutor were familiar to them. Almost all the participants believed that the nature of the grammar class was not conducive to speaking. This indicates the importance of the nature of the task in making WTC dynamic and fluctuating. With regard to classroom interactional pattern, whereas less-WTC students preferred to talk in pairs and small groups, their more-WTC counterparts claimed that it did not make that much difference for them to talk in different situations. Concerning selfperceived L2 proficiency as the linguistic variable in this study, more-WTC students perceived themselves to have a high level of L2 proficiency and as a result, more competent to communicate in English.

The present research bears some resemblance to other classroom-based WTC research in terms of prime dimensions and learner perceptions (Cao, 
2009; de Saint Leger \& Storch, 2009; Pattapong, 2010; Peng, 2008). The three dimensions identified in the present study overlap significantly with the three contexts found in Cao's (2009) and Pattapong's (2010) studies, including individual, situational/social, and cultural contexts. Overall, these studies indicated that both learner internal factors and external classroom conditions could affect classroom WTC, which was supported by the current findings.

What is worthy of notice is that previous research revealed that the three dimensions of individual, contextual and linguistic variables are not distinct but rather are interrelated and overlapping (Kang, 2005; Peng, 2008). In this study, the intertwining relationship among the three dimensions could be better clarified through a few illustrative examples. For instance, Reihaneh's WTC behavior in the Speaking and Listening class was largely determined by the coinfluence of contextual, individual and linguistic factors. Although she claimed that she liked the topic (contextual factor), she justified her silence in two ways. First, she commented that she wanted to talk but other students talked too much; therefore, she couldn't speak more (perceived opportunity to communicate, individual factor). Then, she added she was angry at her classmates' reaction to her mistake (emotion, individual factor) and decided to just listen to the rest of the discussions. Although Reihaneh perceived her proficiency (linguistic factor) above average level and was regarded a moreWTC student by the teacher, she chose to be silent in that particular situation.

The simultaneous and interdependent relationship between different factors could be observed in Bamdad's ideas too. As she put it, "It depends on the interlocutors [contextual factor]. If you are speaking with those who are more knowledgeable than you, it affects the way you are speaking. But if they are the same as you or lower than you, you can speak more easily and you are more confident [individual factor]" (General interview). Elahe's statements could also manifest the nonlinear relationship among the factors. She maintained, "Well, I like the book; I mean I understand what we are studying [task orientation, contextual factor]. And the way the teacher treats us [teacher, interlocutor, contextual factor] and the fact that we are studying together [students, interlocutor, contextual factor], all of these together make me like it [emotion, individual factor]." (Stimulated recall interview) Likewise, Peng (2008) found that WTC in the EFL classroom fluctuated over time and across different situations as a function of the interaction between individual and situational contexts. Results of the current study, however, indicate that in 
addition to individual and contextual factors, linguistic ones might also come into play while determining to initiate or give up interaction (as observed in the case of Reihaneh).

\section{CONCLUSIONS}

The findings of the present study indicated that an interweaving and reciprocal relationship was found between individual, contextual and linguistic dimensions from which the situational WTC behavior emerged (Figure 1).

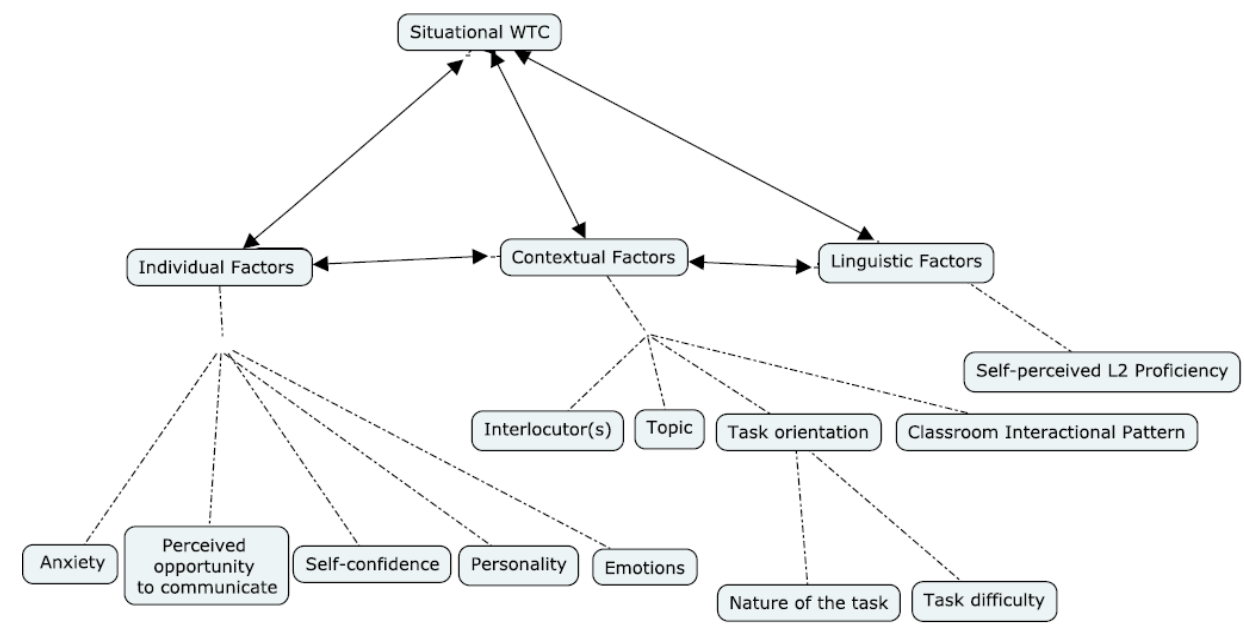

Figure 1. Factors underlying the participants' WTC

Another focus of this study was on understanding the situational aspect of WTC, which is similar to what Shirvan et al. (2020) found with respect to foreign language enjoyment. They pointed to the interaction between individual learners and their learning environments highlighting the dynamic nature of learner-context ecosystem. In a similar vein, the construct of WTC was found not to be stable; instead, it involved fluctuation and dynamism by reason of variations in the individual, contextual, and linguistic precursors. The variables within the three dimensions varied in their amount of facilitative or inhibitive impacts on WTC. All the involved factors varied from lesson to lesson, from 
task to task within a single lesson, and from moment to moment. Thus, their co-influence on situational WTC varied, and in turn, the WTC level could vary correspondingly.

Although the results of this study could offer fascinating insights into our understanding of L2 WTC, it is not void of some limitations. Given that this study was a qualitative case study, it did not intend to examine large random samples to obtain generalizable findings. Although the small sample size in this study could not be considered a limitation of the study, the sample size, along with the sampling procedure, restricts the generalizability of its findings. That being so, further research incorporating mixed-methods studies involving larger randomly selected samples would be of value.

It is also noteworthy that due to the specific nature of the classroom interactional context in this study, a whole-class teacher-fronted context, the participants' communicational behavior was not observed in other conversational contexts such as teacher-absent group activities and pair work. In order to obtain a holistic understanding of learners' situational L2 WTC, it is necessary to observe learners in other conversational contexts. Moreover, since the teachers play a key role in facilitating or impeding learners' L2 WTC, it would be worthwhile for any future research to investigate and incorporate the points of view of teachers on learners' L2 WTC.

Mackey and Gass (2005) recommended the use of video recording when conducting classroom observations because video recording enables the researcher to comment on the non-verbal communication that is taking place, providing more than just verbal information. Nevertheless, we were not allowed to record the class sessions because of some legislative restrictions existing at universities as well as observed teachers' reluctance to be recorded. Therefore, it is highly recommended that other researchers attempt to use video recording in similar future studies to obtain a greater range of data.

Despite these limitations, the current study contributes evidence of the potential of manipulating students' WTC due to its dynamic nature in classroom contexts. Informed by and building upon the findings of this study along with similar findings of previous research, it could safely be argued that in EFL contexts like Iran where L2 learning primarily occurs in a classroom setting, creating a situation that engenders and enhances students' L2 WTC in the classroom plays a leading role in boosting students' L2 learning. Since EFL students may not have immediate access to native English speakers either 
inside or outside the classroom context to have real life conversations, instructors need to create environments for the students to communicate in English in the classroom.

Also, based on the same findings, the participants' L2 WTC was higher when they were familiar with the topic of discussion. Offering real-life examples, i.e. relating the text with real life situations, can create more opportunities for learners to elaborate on the topic. Additionally, the teacher's behavior was found to exert a considerable influence on learners' participation in class activities. A teacher's friendly behavior, empathy towards learners, and enthusiasm for the topic of discussion could work a great deal towards enhancing learners' L2 WTC.

Another related issue identified in the current study was the lack of perceived opportunities to use the L2. This issue is typically linked with the whole-class contextual situation and classroom management on the part of the teacher. In order to alleviate this problem, teachers could exploit different interactional patterns such as group work and dyad. Pairing up learners into small groups or dyads will allow them to remove the psychological barriers such as anxiety and help them initiate interaction.

\section{REFERENCES}

Alemi, M., Daftarifard, P., \& Pashmforoosh, R. (2011). The Impact of language anxiety and language proficiency on WTC in EFL context. Cross-Cultural Communication, 7(3), 150-166. http://dx.doi.org/10.3968/j.ccc.1923670020110703.152

Alimorad, Z. (2013). Discursive motivation/demotivation construction: A case of Iranian EFL majors. (Unpublished Ph.D. dissertation, Shiraz University, Shiraz, Fars, Iran).

Ary, D., Jacobs, L. C., Sorensen, C., Walker, D. A. (2019). Introduction to research in education (10 th ed.). Cengage Learning.

Baker, S. C., \& MacIntyre, P. D. (2003). The role of gender and immersion in communication and second language orientations. Language Learning, 53(1), 65-96. https://doi.org/10.1111/0023-8333.00224

Cao, Y. Q. (2009). Understanding the notion of interdependence and the dynamics of willingness to communicate. (Unpublished Ph.D. dissertation, The University of Auckland, Auckland, New Zealand). 
Cao, Y. (2011). Investigating situational willingness to communicate within second language classrooms from an ecological perspective. System, 39(4), 468-479. https://doi.org/10.1016/j.system.2011.10.016

Cao, Y. (2014). A sociocognitive perspective on second language classroom willingness to communicate. TESOL Quarterly, 48, 789-814. https://doi.org/10.1002/tesq.155

Cao, Y., \& Philp, J. (2006). Interactional context and willingness to communicate: A comparison of behavior in whole class, group and dyadic interaction. System, 34(4), 480-493. https://doi.org/10.1016/j.system.2006.05.002

Cetinkaya, Y. B. (2005). Turkish college students' willingness to communicate in English as a foreign language. (Unpublished Ph.D. dissertation, Ohio State University, Ohio, U.S.A.). Retrieved from https://etd.ohiolink.edu/apexprod/rws_etd/send_file/send?accession=osu1 133287531\&disposition=inline

Clément, R., Baker, S. C., \& MacIntyre, P. D. (2003). Willingness to communicate in a second language: The effects of context, norms, and vitality. Journal of Language and Social Psychology, 22(2), 190-209. https://doi.org/10.1177\%2F0261927X03022002003

Clément, R., Dörnyei, Z., \& Noels, K. A. (1994). Motivation, self-confidence, and group cohesion in the foreign language classroom. Language Learning, 44(3), 417-448. https://psycnet.apa.org/doi/10.1111/j.14671770.1994.tb01113.x

de Saint Leger, D., \& Storch, N. (2009). Learners' perceptions and attitudes: Implications for willingness to communicate in an L2 classroom. System, 37(2), 269-285. https://doi.org/10.1016/j.system.2009.01.001

Fallah, N. (2014). Willingness to communicate in English, communication selfconfidence, motivation, shyness and teacher immediacy among Iranian English-major undergraduates: A structural equation modeling approach, Learning and Individual Differences, 30, 140-147. https://doi.org/10.1016/j.lindif.2013.12.006

Freiermuth, M. R., \& Ito, M. F. (2020). Seeking the source: The effect of personality and previous experiences on university students' L2 willingness to communicate. Learning and Motivation, 71, 1-13. https://doi.org/10.1016/j.lmot.2020.101640 
Ghonsooly, B., Khajavy, G. H., \& Asadpour, S. F. (2012). Willingness to communicate in English among Iranian non-English major university students. Journal of Language and Social Psychology, 31(2), 197-211. https://doi.org/10.1177\%2F0261927X12438538

Goetz, T., Pekrun, R., Hall, N., \& Haag, L. (2006). Academic emotions from a social-cognitive perspective: Antecedents and domain specificity of students' affect in the context of Latin instruction. British Journal of Educational Psychology, 76(2), 289-308. https://doi.org/10.1348/000709 $905 \times 42860$

House, J. A. (2004). Learner perceptions of willingness to communicate. (Unpublished M.A. Thesis, The University of Auckland, Auckland, New Zealand).

Johnson, B., \& Christensen, L. (2008). Educational research: Quantitative, qualitative, and mixed approaches ( $2^{\text {nd }}$ ed.). Pearson.

Kang, S. J. (2005). Dynamic emergence of situational willingness to communicate in a second language. System, 33(2), 277-292. https://doi.org/10.1016/j.system.2004.10.004

Khajavy, G. H., Ghonsooly, B., Hosseini Fatemi, A. \& Choi, C. W. (2014). Willingness to communicate in English: A microsystem model in the Iranian EFL classroom context. TESOL Quarterly, 50(1), 154-180. https://doi.org/10.1002/tesq.204

Khajavy, G. H., MacIntyre P. D., \& Barabadi, E. (2018). Role of the emotions and classroom environment in willingness to communicate: Applying doubly latent multilevel analysis in second language acquisition research. Studies in Second Language Acquisition, 40, 605-624. http://doi.org/10.1017/S0272263117000304

Kim, S. J. (2004). Exploring willingness to communicate (WTC) in English among Korean EFL (English as a foreign language) students in Korea: WTC as a predictor of success in second language acquisition. (Unpublished Ph.D. dissertation, Ohio State University, Ohio, U.S.A.). Retrieved from https://etd.ohiolink.edu/apexprod/rws_olink/r/1501/10?clear=10\&p10_acc ession_num $=$ osu1101267838\#abstract-files

Liu, M. H. (2005). Reticence in oral English language classrooms: A case study in China. TESL Reporter, 38(1), 1-16. Retrieved from https://contentdm.lib.byu.edu/digital/collection/TESL/id/1469/ 
Liu, M. H., \& Jackson, J. (2008). An exploration of Chinese EFL learners' unwillingness to communicate and foreign language anxiety. The Modern Language Journal, 92(1), 71-86. https://doi.org/10.1111/j.1540-4781. 2008.00687.x

MacIntyre, P. D. (2007). Willingness to communicate in the second language: Understanding the decision to speak as a volitional process. The Modern Language Journal, 91(4), 564-576. https://doi.org/10.1111/j.15404781.2007.00623.x

MacIntyre, P. D., \& Charos, C. (1996). Personality, attitudes, and affect as predictors of second language communication. Journal of Language and Social Psychology, 15(1), 3-26. https://doi.org/10.1177\%2F0261927X960 151001

MacIntyre, P. D., Clément, R., Dörnyei, Z., \& Noels, K. A. (1998). Conceptualizing willingness to communicate in a L2: A situational model of L2 confidence and affiliation. The Modern Language Journal, 82(4), 545-562. https://doi.org/10.2307/330224

MacIntyre, P. D., Baker, S. C., Clément, R., \& Conrod, S. (2001). Willingness to communicate, social support, and language-learning orientations of immersion students. Studies in Second Language Acquisition, 23(3), 369388. https://doi.org/10.1017/S0272263101003035

MacIntyre, P. D., Baker, S. C., Clément, R., \& Donovan, L. A. (2003). Sex and age effects on willingness to communicate, anxiety, perceived competence, and L2 motivation among junior high school French immersion students. Language Learning, 53(S1), 137-166. https://doi.org/10.1111/1467-9922.00226

MacIntyre, P. D., \& Legatto, J. J. (2011). A dynamic system approach to willingness to communicate: Developing an idiodynamic method to capture rapidly changing affect. Applied Linguistics, 32(2), 149-171. https://doi.org/10.1093/applin/amq037

Mackey, A., \& Gass, S. M. (2005). Second language research: Methodology and design. LEA Publishers.

MacKinnon, S. P., Hall, S., \& MacIntyre, P. D. (2007). Origins of the stuttering stereotype: Stereotype formation through anchoring-adjustment. Journal of Fluency Disorders, 32(4), 297-309. https://doi.org/10.1016/j.jfludis.2007.03.003 
McCroskey, J. C., \& Baer, J. E. (1985, November). Willingness to communicate: The construct and its measurement. Paper presented at the meeting of the Annual Convention of the Speech Communication Association, Denver, CO. Retrieved from https://files.eric.ed.gov/fulltext/ ED265604.pdf

McCroskey, J. C., \& Richmond, V. P. (1990). Willingness to communicate: Differing cultural perspectives. Southern Journal of Communication, 56(1), 72-77. https://doi.org/10.1080/10417949009372817

McCroskey, J. C., \& Richmond, V. P. (1991). Willingness to communicate: A cognitive view. In M. Booth-Butterfield (Ed.), Communication, cognition, and anxiety (pp. 19-37). Sage.

Mystkowska-Wiertelak, A. (2018). Fluctuations in willingness to communicate during a semester: A case study, The Language Learning Journal, 49(1), 1-12. http://doi.org/10.1080/09571736.2018.1469660

Öz, H., Demirezen. M., \& Pourfeiz. J. (2015). Willingness to communicate of EFL learners in Turkish context. Learning and Individual Differences, 37, 269-275. https://doi.org/10.1016/j.lindif.2014.12.009

Pattapong, K. (2010). Willingness to communicate in a second language: A qualitative study of issues affecting Thai EFL learners from students' and teachers' points of view. (Unpublished Ph.D. dissertation, University of Sydney, Sydney, Australia).

Pekrun, R. (2000). A social-cognitive, control-value theory of achievement emotions. In J. Heckhausen (Ed), Advances in psychology, 131. Motivational psychology of human development: Developing motivation and motivating development (pp. 143-163). Elsevier science.

Pekrun, R., Goetz, T., Titz, W., \& Perry, R. P. (2002). Academic emotions in students' self-regulated learning and achievement: A program of qualitative and quantitative research. Educational Psychologist, 37(2), 91105. https://doi.org/10.1207/S15326985EP3702_4

Peng, J. E. (2008, August). Dynamic fluctuations of willingness to communicate in Chinese EFL classroom: A multiple case study. Paper presented in the 15th World Congress of Applied Linguistics, Essen, Germany.

Peng, J. E. (2012). Towards an ecological understanding of willingness to communicate in EFL classrooms in China. System, 40(2), 203-213. https://doi.org/10.1016/j.system.2012.02.002 
Peng, J. E., \& Woodrow, L. (2010). Willingness to communicate in English: A model in the Chinese EFL classroom context. Language Learning, 60(4), 834-876. https://doi.org/10.1111/j.1467-9922.2010.00576.x

Riasati, M. J. (2012). EFL learners' perception of factors influencing willingness to speak English in language classrooms: A qualitative study. World Applied Sciences, 17(10), 1287-1297. Retrieved from http://www.idosi.org/wasj/wasj17(10)12/9.pdf

Robson, G. (2015). A model of situational willingness to communicate (WTC) in the study abroad context. International Education Studies, 8(10), 114125. http://dx.doi.org/10.5539/ies.v8n10p114

Shirvan, M, Taherian, T., \& Yazdanmehr, E. (2020). The dynamics of foreign language enjoyment: An ecological momentary assessment. Frontiers in Psychology, 11, 1-14. http://doi.org/ 10.3389/fpsyg.2020.01391

Wen, W. P., \& Clément, R. (2003). A Chinese conceptualisation of willingness to communicate in ESL. Language, Culture and Curriculum, 16(1), 18-38. https://doi.org/10.1080/07908310308666654

Yashima, T. (2002). Willingness to communicate in a second language: The Japanese EFL context. The Modern Language Journal, 86(1), 54-66. https://doi.org/10.1111/1540-4781.00136

Yashima, T., Zenuk-Nishide, L., \& Shimizu, K. (2004). The influence of attitudes and affect on willingness to communicate and second language communication. Language Learning, 54(1), 119-152. https://doi.org/10.1111/j.1467-9922.2004.00250.x

Yashima, T., MacIntyre, P. D. \& Ikeda, M. (2016). Situated willingness to communicate in an L2: Interplay of individual characteristics and context. Language Teaching Research, 22(1), 115-137. http://doi.org/10.1177/1362168816657851.

Zarrinabadi, N. (2014). Communicating in a second language: Investigating the effect of teacher on learners' willingness to communicate. System, 42, 288-295. https://doi.org/10.1016/j.system.2013.12.014 
28 TEFLIN Journal, Volume 32, Number 1, January 2021

\section{Appendix}

\section{CLASSROOM OBSERVATION SCHEME}

\begin{tabular}{|c|c|}
\hline Categories & Descriptions \\
\hline \multirow{2}{*}{$\begin{array}{l}\text { Volunteer an answer/a } \\
\text { comment (hand-raising } \\
\text { included) }\end{array}$} & $\begin{array}{l}\text { A student answers a question raised by the teacher to the } \\
\text { whole class. }\end{array}$ \\
\hline & A student volunteers a comment. \\
\hline \multirow{2}{*}{$\begin{array}{l}\text { Give an answer to the } \\
\text { teacher's question }\end{array}$} & $\begin{array}{l}\text { A student responds to a question addressed to the group } \\
\text { or a group member (teacher solicit). }\end{array}$ \\
\hline & $\begin{array}{l}\text { A student responds to a question addressed to another } \\
\text { group or an individual student (private response). }\end{array}$ \\
\hline $\begin{array}{l}\text { Ask the teacher a } \\
\text { question }\end{array}$ & A student asks the teacher a question or for clarification. \\
\hline $\begin{array}{l}\text { Try out a difficult form } \\
\text { in the target language }\end{array}$ & $\begin{array}{l}\text { A student attempts at a difficult lexical, morphological } \\
\text { or syntactical form. }\end{array}$ \\
\hline $\begin{array}{l}\text { Guess the meaning of } \\
\text { an unknown word }\end{array}$ & $\begin{array}{l}\text { A student makes an attempt to guess the meaning of an } \\
\text { unknown word. }\end{array}$ \\
\hline $\begin{array}{l}\text { Present own opinions in } \\
\text { class/ respond to an } \\
\text { opinion }\end{array}$ & A student voices his view to the class or his group. \\
\hline $\begin{array}{l}\text { Volunteer to } \\
\text { participate in class } \\
\text { activities }\end{array}$ & A student takes part in an activity. \\
\hline \multirow[t]{2}{*}{$\begin{array}{l}\text { Talk to neighbor/ } \\
\text { another group member }\end{array}$} & $\begin{array}{l}\text { A student talks to another group member or a student } \\
\text { from another group as part of a lesson or as informal } \\
\text { socializing. }\end{array}$ \\
\hline & A student asks a group member / partner a question. \\
\hline
\end{tabular}

